\title{
Pengembangan Buku Ajar Bahasa Indonesia Terintegrasi Pendidikan Karakter Berdasarkan Pendekatan Komunikatif
}

\author{
Cicilia Nian Erika \\ Universitas Sanata Dharma \\ nianerika25@gmail.com
}

How to cite (in APA Style): Erika, C.N. (2019). Pengembangan buku ajar bahasa Indonesia terintegrasi pendidikan karakter berdasarkan pendekatan komunikatif. Jurnal Pendidikan Bahasa dan Sastra, 19(2), 267-279. DOI: https://doi.org/10.17509/bs_jpbsp.v19i2.24832

Article History: Received (06 August 2019); Revised (15 September 2019); Accepted (1 October 2019). Journal homepage: http://ejournal.upi.edu./index.php/BS_JPBSP

\begin{abstract}
Abstrak: Penelitian dan pengembangan buku ajar bahasa Indonesia sangat penting dilakukan terutama untuk buku ajar yang mengintegrasikan pendidikan karakter berdasarkan pendekatan komunikatif. Telah banyak buku ajar yang terbit namun seringkali hanya untuk acuan dalam tugas dan latihan. Buku ajar yang ada pun belum sepenuhnya menggunakan teks yang menjadi genre dalam pembelajaran bahasa Indonesia, yaitu pedagogik genre. Penelitian ini bertujuan untuk menghasilkan wujud kompetensi, wujud materi, wujud tugas, dan wujud penilaian dalam pengembangan buku ajar Bahasa dan Sastra Indonesia terintegrasi dengan pendidikan karakter berdasarkan pendekatan komunikatif untuk jenjang pendidikan SMP. Metode penelitian yang digunakan yaitu penelitian dan pengembangan dengan mengacu pada model Borg and Gall. Hasil penelitian menunjukkan bahwa perangkat pembelajaran, buku ajar, telah layak diimplementasikan. Selain itu, penilaian praktisi terhadap implementasi buku ajar ini adalah 3,526 kategori "Baik". Begitu pula dengan penilaian peserta didik untuk tiga aspek menduduki kategori Baik yang paling tinggi. Oleh karena itu, pengembangan buku ajar Bahasa dan Sastra Indonesia ini sudah dapat dikatakan layak untuk digunakan dan menjawab kebutuhan dari pendidik dan peserta didik di SMP Pangudi Luhur 1 Yogyakarta.
\end{abstract}

Kata kunci: buku ajar; pendidikan karakter; bahasa Indonesia; pendekatan komunikatif

\section{The Development of Indonesian Textbooks Integrated with Character Education Based on Communicative Approach}

\begin{abstract}
The research and development of Indonesian textbooks is very important especially for the textbook which integrates character education using communicative approach. Many textbooks have been published, but they are often only for reference in assignments and exercises. The existing textbooks do not fully use text that is a genre in learning Indonesian, namely the pedagogic genre. This research aims to produce forms of competence, material forms, forms of tasks, and forms of assessment in the development of Indonesian Language and Literature textbooks integrated with character education based on communicative approaches for junior high school. The method used was research and development with reference to the Borg and Gall model. The showed that learning devices, teaching books, are feasible to implement. In addition, practitioners' assessment of the implementation of this textbook is 3,526 categories "Good". Likewise, the assessment of students in the three aspects occupies the highest category of Good. Therefore, the development of the Indonesian Language and Literature textbook can already be said to be feasible to use for the teachers and the students of Junior High School, especially for SMP Pangudi Luhur 1 in Yogyakarta.
\end{abstract}

Keywords: textbooks; character education; Indonesian language; communicative approach 


\section{PENDAHULUAN}

Bahasa Indonesia merupakan sarana komunikasi dan sastra merupakan salah satu hasil budaya yang menggunakan bahasa sebagai sarana kreativitas. Sementara itu, bahasa dan sastra Indonesia seharusnya diajarkan kepada peserta didik melalui pendekatan yang sesuai dengan hakikat dan fungsinya. Pendekatan yang dimaksud adalah pendekatan pembelajaran bahasa yang menekankan aspek kinerja atau keterampilan berbahasa dan fungsi bahasa. Pendekatan itu adalah pendekatan komunikatif (Wahyuni \& Ibrahim, 2013, p.50). Para pakar linguistik terapan Inggris memberikan penekanan pada dimensi fundamental bahasa lainnya yang tidak mendapat perhatian yang layak dalam pendekatan-pendekatan mutakhir terhadap pengajaran bahasa pada masa itu, yaitu potensi bahasa yang bersifat fungsional dan komunikatif. Mereka melihat betapa perlunya memfokuskan kecakapan komunikatif dalam pengajaran bahasa dan tidak terus-menerus membahas mengenai penguasaan struktur saja (Tarigan, 1988,p.270).

Kecakapan komunikatif menjadi sangat penting dalam kehidupan di masa depan peserta didik. Terampil dalam berkomunikasi, baik secara lisan maupun tulis, menunjukkan tingkat intelektual peserta didik. Berkomunikasi secara lisan pada beragam situasi sosial haruslah dapat sesuai dengan lingkungan. Hal ini menjadi bentuk manusia yang dapat beradaptasi pada beragam situasi lingkungan. Kecapakan komunikatif ini tentunya memerlukan sumbangsih yang utama, yaitu pendidikan. Pendidikan itu bukan hanya di bangku sekolah. Pendidikan itu dimulai sejak dari dalam rahim ibu sampai sepanjang hayat. Hal ini berarti bahwa pendidikan itu tidak ada putus-putusnya sampai manusia itu meninggal. Listyarti (2012,p.2) mengungkapkan bahwa pendidikan adalah sebuah proses untuk mengubah jati diri seorang peserta didik untuk lebih maju.
Pendidikan itu memiliki dasar, fungsi, dan tujuan. Dalam Dasar, Fungsi, dan Tujuan, Pasal 3, UU RI Nomor 20 tahun 2003 tentang Sistem Pendidikan Nasional, pasal ini berbunyi, "Pendidikan Nasional berfungsi mengembangkan kemampuan dan membentuk watak serta peradaban bangsa yang bermartabat, dalam rangka mencerdaskan kehidupan bangsa, bertujuan untuk berkembangnya potensi peserta didik agar menjadi manusia yang beriman dan bertakwa kepada Tuhan Yang Maha Esa, berakhlak mulia, sehat, berilmu, cakap, kreatif, mandiri, dan menjadi warga negara yang demokratis serta bertanggung jawab” (Kurniawan, 2013,p.38).

Fungsi Pendidikan Nasional sudah tertuang dalam UU RI yang juga menuntut adanya integrasi antara keterampilan abad 21 dan pendidikan karakter. Sebagai seorang pendidik dan calon pendidik, ini adalah suatu tantangan yang harus, mau tidak mau dihadapi. Tantangan ini pun bukan hanya untuk para pendidik, melainkan juga untuk seluruh elemen masyarakat Indonesia yang tersebar dari Sabang sampai Merauke.

Pendidikan karakter dan pendekatan komunikatif tentunya dapat diintegrasikan dalam pembelajaran dan sangat relevan, salah satunya adalah mata pelajaran Bahasa Indonesia. Dalam pembelajaran ini ada beragam karakter yang bisa diterapkan, sama dengan yang tertuang dalam dasar, fungsi, dan tujuan pendidikan, yaitu beriman dan bertakwa kepada Tuhan Yang Maha Esa, berakhlak mulia, sehat, berilmu, cakap, kreatif, mandiri, dan menjadi warga negara yang demokratis serta bertanggung jawab. Beberapa karakter yang diharapkan itu memiliki kesamaan dengan karakter yang diharapkan di SMP Pangudi Luhur 1 Yogyakarta, yaitu luhur budi, cerdas, peduli lingkungan, dan humanis.

Pendidikan di sekolah mencakup banyak aspek pembangun, selain guru, peserta didik, kelas, sarana prasarana, dan perangkat di sekolah. Sarana prasarana yang selalu terlihat dan digunakan adalah 
buku ajar. Buku ajar yang beredar di masyarakat selalu mengalami perbaruan yang bertujuan memberikan yang terbaik dalam pendidikan. Namun, buku ajar yang mengintegrasikan pendidikan karakter dan pendekatan komunikatif belum banyak beredar dan pengimplementasiannya belum sesuai. Buku ajar yang ada cenderung mementingkan aspek kognitif. Adapun untuk aspek sikap dan keterampilan dapat dikatakan belum optimal. Bahkan, aspek sikap sekarang mulai dikotakkan dalam pembelajaran agama dan kewarganegaraan. Padahal, dalam pelajaran Bahasa Indonesia, sikap berbahasa adalah penting agar maksud dari pembicara dapat tersampaikan dengan baik tanpa menimbulkan hal di luar topik. Selain itu, sikap berbahasa pula tetap harus dijaga agar tidak terjadi debat dan polemik yang negatif atau destruktif. Sikap berbahasa tidak akan terealisasi dengan baik tanpa adanya keterampilan berbahasa. Keterampilan berbahasa sesuai dengan konteks sosial budaya membuat komunikasi berjalan lancar dan berkualitas baik. Maka dari itu, penelitian dan pengembangan ini dilakukan untuk menyusun sebuah buku ajar Bahasa dan Sastra Indonesia terintegrasi pendidikan karakter berdasarkan pendekatan komunikatif.

Terdapat sejumlah penelitian yang dilakukan berkaitan dengan pengembangan buku ajar terintegrasi pendidikan karakter (Nurdyansyah, \& Lestari, 2018; Riyanto, 2013; Suwarni, 2015; Situmorang, 2014; Irawati, \& Elmubarok, 2014; Tolla, 1996, Rabawati, et al., 2013). Dalam penelitian yang dilakukan oleh Tolla (1996) diperoleh data bahwa (1) pemahaman guru tentang prinsip-prinsip pendekatan komunikatif yang mendasari kurikulum bahasa Indonesia masih terbatas. Oleh karena itu, guru kurang mampu mengajarkan materi kurikulum yang telah dijabarkan ke dalam unit-unit pembelajaran di dalam buku paket, (2) materi pelajaran yang disusun dan disajikan oleh guru masih berorientasi pada pengetahuan bahasa, bukan pada keterampilan berbahasa, (3) strategi belajar-mengajar yang digunakan oleh guru masih berpola guru sebagai pusat kegiatan belajar-mengajar, (4) peran peserta didik dalam proses belajar-mengajar lebih banyak bersifat pasif reseptif daripada aktif produktif, dan (5) guru jarang atau tidak melakukan penilaian dalam proses belajarmengajar, sehingga kemajuan peserta didik dalam setiap kegiatan belajar tidak dapat diidentifikasi.

Penelitian mengenai pendekatan komunikatif pada pembelajaran bahasa Indonesia pernah dilakukan pula oleh Rabawati, et al., (2013) yang menyatakan bahwa guru sudah menerapkan pendekatan komunikatif dengan tepat dalam pembelajaran bahasa Indonesia dengan penekanan pada keaktifan peserta didik. Peran guru sebagai fasilitator yang hanya menjelaskan pelajaran jika diperlukan. Hambatan yang dialami oleh guru adalah sebagai berikut. Peserta didik masih tampak malu dalam mengemukakan pendapatnya, bahasa Indonesia yang digunakan banyak yang tidak sesuai dengan kaidah, mencari materi yang cocok untuk semua peserta didik dan yang menarik perhatian, dan membutuhkan waktu yang lebih banyak dalam penerapan di kelas. Pendekatan komunikatif merupakan salah satu pendekatan yang memungkinkan guru menggunakan metode dan teknik untuk lebih mambantu dalam memotivasi peserta didik dalam mengembangkan kompetensi komunikatif.

Dalam kehidupan sehari-hari, fungsi utama bahasa adalah sarana komunikasi. Bahasa dipergunakan sebagai alat untuk berkomunikasi antar penutur untuk berbagai keperluan dan situasi pemakaian. Untuk itu, orang tidak akan berpikir tentang sistem bahasa, tetapi berpikir bagaimana menggunakan bahasa ini secara tepat sesuai dengan konteks dan situasi. Jadi, secara pragmatis, bahasa lebih merupakan suatu bentuk kinerja dan performansi daripada sebuah sistem ilmu. Pandangan ini membawa konsekuensi bahwa pelajaran bahasa haruslah menekankan fungsi bahasa sebagai alat komunikasi daripada pembelajaran tentang sistem bahasa (Wahyuni \& Ibrahim, 2013, 
p.51). Pandangan ini belum sepenuhnya diaminkan oleh pelaku-pelaku bahasa di dunia pendidikan. Hal ini terbukti dengan pembelajaran yang berbasis teori dan minim praktik. Notabene pelajaran bahasa Indonesia di sekolah haruslah menyiapkan peserta didik menjadi generasi yang dapat berinterkasi dengan masyarakat dan dunia kerja.

$\begin{array}{rrrr} & \text { Pembelajaran } & \text { Bahasa } & \text { Indonesia } \\ \text { Kurikulum } & 2013 & \text { revisi } & 2017\end{array}$
(Kemendikbud, 2017) merupakan sintesis dari tiga pendekatan, yaitu pedagogi genre, saintifik, dan Content and Language Integrated Learning (CLIL). Alur utama model adalah pedagogi genre dengan $4 \mathrm{M}$, yaitu: (1) Membangun Konteks, (2) Menelaah Model, (3) Mengonstruksi Terbimbing, dan (4) Mengonstruksi Mandiri. Adapun kegiatan mendapatkan pengetahuan (KD-3) dilakukan dengan pendekatan saintifik 5M, yaitu: (1) Mengamati, (2) Mempertanyakan, (3) Mengumpulkan Informasi, (4) Menalar, dan (5) Mengomunikasikan. Sedangkan untuk pengembangan keterampilan (KD-4) dilanjutkan dengan langkah mengonstruksi terbimbing dan mengonstruksi mandiri. Pendekatan CLIL digunakan untuk memperkaya pembelajaran dengan prinsip, 1) isi (konten) teks-berupa model atau tugs-bermuatan karakter dan pengembangan wawasan serta kepedulian sebagai warga negar dan sebagai warga dunia, 2) unsur kebahasaan (komunikasi) menjadi unsur penting untuk menyatakan berbagai tujuan berbagasa dalam kehidupan, 3) setiap jenis teks memiliki struktur berpikir (kognisi) yang berbedabeda yang harus disadari agar komunikasi lebih efektif, dan 4) budaya (kultur), berbahasa, berkomunikasi yang berhasil harus melibatkan etika, kesantunan berbahasa, budaya (antarbangsa, nasional, dan lokal).

Penelitian yang berkaitan dengan pendidikan karakter dan pembelajaran bahasa sastra Indonesia, salah satunya penelitian milik Lis Setiawati yang berjudul Pembentukan Karakter Siswa melalui Pembelajaran Bahasa dan Sastra Indonesia.
Hasil dari penelitian ini berupa pernyataan sebagai berikut. Guru profesional, berakhlak mulia, berpengetahuan luas adalah modal utama bagi kemajuan dunia pendidikan kita. Tanpa hal ini, harapan menjadi negara besar dengan bangsa terhormat dan berwibawa hanya akan menjadi angan-angan. Tugas berat bertumpu di pundak pahwalan pendidikan. Jika tidak ingin atau tidak sanggup mengemban tugas ini, lebih baik beralih ke profesi lain dengan tugas yang lebih ringan.

Karakter memiliki tiga bagian yang saling berhubungan: pengetahuan moral, perasaan moral, dan perilaku moral. Karakter yang baik terdiri dari mengetahui hal yang baik, menginginkan hal yang baik, dan melakukan hal yang baik-kebiasaan dalam cara berpikir, kebiasaan dalam hati, dan kebiasaan dalam bertindak. Ketika berpikir tentang jenis karakter yang diinginkan bagi anak-anak, sudah jelas bahwa anak-anak mampu menilai apa yang benar, sangat peduli tentang apa yang benar, dan melakukan apa yang mereka yakini itu benar-meskipun berhadapan dengan godaan dari dalam dan tekanan dari luar (Lickona, 2013,p.82).

Kita mengetahui bahwa strategi pembelajaran abad 21 ini diimplementasikan guru di dalam kelas dengan memenuhi beberapa karakteristik. Karakteristik yang dimaksud, antara lain: pembelajaran berpusat pada peserta didik (student centered); mengembangkan kreativitas peserta didik; menciptakan suasana yang menarik, menyenangkan, dan bermakna; mengembangkan beragam kemampuan yang bermuatan nilai dan makna; belajar melalui berbuat, yakni peserta didik aktif berbuat; menekankan pada penggalian, penemuan, penciptaan; dan menciptakan pembelajaran dalam situasi nyata dan konteks sebenarnya, yakni melalui pendekatan kontekstual (Hosnan, 2014,p.85).

Penelitian dan pengembangan buku ajar Bahasa dan Sastra Indoesia ini bertujuan untuk menghasilkan wujud kompetensi, wujud materi, wujud tugas, dan wujud penilaian dalam pengembangan 
buku ajar Bahasa dan Sastra Indonesia terintegrasi dengan pendidikan karakter berdasarkan pendekatan komunikatif untuk jenjang pendidikan SMP Pangudi Luhur 1 Yogyakarta kelas VIII tahun ajaran 2019/2020.

\section{METODE}

Penelitian ini merupakan penelitian pengembangan (research and development) dengan menghasilkan buku ajar Bahasa dan Sastra Indonesia terintegrasi pendidikan karakter berdasarkan pendekatan komunikatif di SMP Pangudi Luhur 1 Yogyakarta kelas VIII. Menurut Sugiyono (2015,p.407), metode penelitian dan pengembangan adalah metode pengembangan yang digunakan untuk menghasilkan produk tertentu dan menguji keefektifan produk tersebut. Model pengembangan yang diacu dalam penelitian pengembangan ini adalah model pengembangan Borg and Gall. Berikut kesepuluh langkah model pengembangan Borg and Gall.

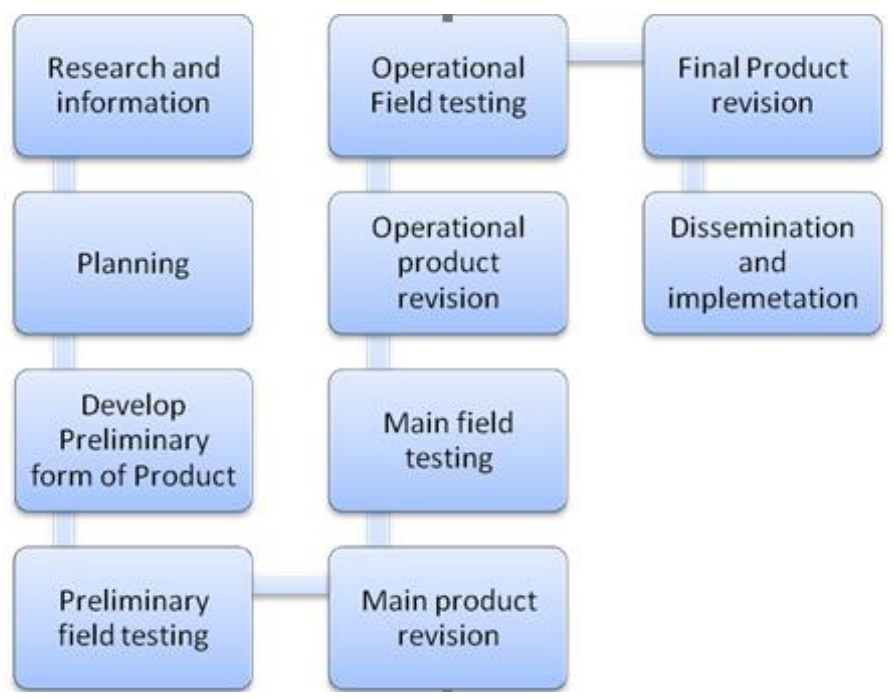

Gambar 1. Metode Penelitian dan Pengembangan Model Borg and Gall

Dalam penelitian pengembangan ini tidak melalui kesepuluh tahap. Penelitian ini hanya sampai pada tahap keenam, yaitu main field testing, atau ujicoba di lapangan di kelas VIII D SMP Pangudi Luhur 1 Yogyakarta. Tahap yang dilalui adalah research and information collecting, planning, develop preliminary form of product, preliminary field testing, main product revision, dan main field testing.

Populasi penelitian ini adalah seluruh warga SMP Pangudi Luhur 1 Yogyakarta. Adapun sampel yang digunakan dalam penelitian ini peneliti sebut sebagai sumber data. Sumber data penelitian pengembangan ini adalah SMP Swasta Pangudi Luhur Yogyakarta 1. Populasinya adalah peserta didik SMP Pangudi Luhur 1 Yogyakarta kelas VIII tahun ajaran 2019/2020. Sampel dari penelitian ini adalah satu kelas VIII yang dipilih secara random. Tidak hanya itu, sumber data penelitian ini adalah kepala sekolah dan guru mata pelajaran Bahasa Indonesia.

Teknik pengumpulan data awal pada penelitian dan pengembangan ini melalui interview (wawancara) guru mata pelajaran bahasa Indonesia dan kepala sekolah di SMP Pangudi Luhur 1 Yogyakarta. Selain itu, pengumpulan data penelitian ini melalui lembar kuesioner yang berisi analisis kebutuhan yang nantinya akan diisi oleh peserta didik di SMP Pangudi Luhur 1 Yogyakarta kelas VIII. Wawancara dilakukan untuk analisis kebutuhan. Sumber data yang diwawancarai adalah guru mata pelajaran Bahasa 
Indonesia dan kepala sekolah di SMP Pangudi Luhur 1 Yogyakarta. Untuk melakukan wawancara dan pembagian kuesioner tersebut, peneliti sebelumnya meminta validasi instrumen kepada dua validator yang bergelar minimal Doktor. Kedua validator tersebut adalah Drs. Pius Nurwidasa P., M.Ed., Ed.D., dan Drs. Barli Bram, M.Ed., Ph.D. Selain itu, untuk kuesioner sudah dilakukan uji coba kepada beberapa peserta didik usia SMP kelas VIII dari sekolah yang lain. Hal ini dilakukan agar kata-kata yang digunakan dalam kuesioner dapat dipahami oleh peserta didik kelas VIII.

Teknik pengumpulan data yang kedua pada penelitian pengembangan ini adalah dengan dilakukannya validasi produk buku ajar yang dilakukan oleh ahli materi dan ahli media. Namun sebelumnya, instrumen validasi produk yang akan digunakan oleh para ahli materi, ahli media, dan praktisi divalidasi terlebih dahulu oleh ahli instrumen. Para ahli instrumen yang memvalidasi instrumen validasi produk pada penelitian ini adalah Prof. Dr. Anik Ghufron, M.Pd., dan Dr. Christina Ismaniati, M.Pd., keduanya Dosen Kurikulum dan Teknologi Pendidikan, Universitas Negeri Yogyakarta. Setelah instrumen validasi proses divalidasi oleh kedua ahli instrumen tersebut, produk yang sudah jadi divalidasi oleh ahli media dan ahli materi, yaitu Dr. Engkos Kosasih, M.Pd., dan Prof. Dr. Praptomo Baryadi Isodarus, M.Hum.

Teknik pengumpulan data yang ketiga juga masih sama dengan teknik pengumpulan data yang kedua, yaitu dengan kuesioner. Kuesioner tersebut disebut kuesioner umpan balik karena diisi setelah produk buku ajar digunakan dalam pembelajaran Bahasa Indonesia. Kuesioner tersebut diisi oleh guru mata pelajaran Bahasa Indonesia kelas VIII dan peserta didik kelas VIII SMP Pangudi Luhur 1 Yogyakarta. Sama halnya dengan intrumen sebelumnya, instrumen umpan balik ini sebelum digunakan akan divalidasi oleh ahli instrumen. Ahli instrumen yang memvalidasi instrumen umpan balik sama dengan ahli instrumen yang memvalidasi instrumen validasi ahli materi dan media. Namun, sebelum diujicoba dan dimintakan umpan balik dari peserta didik dan praktisi, buku ajar yang sudah jadi divalidasi oleh ahli materi dan media dengan menggunakan kuesioner pula. Kedua ahli materi dan media yang memvalidasi adalah Prof. Dr. Praptomo Baryadi Isodarus, M.Hum., dan Dr. Engkos Kosasih, M.Pd.

Data yang diperoleh dalam penelitian ini selajutnya dikumpulkan, disajikan, dan dianalisis menggunakan strategi kuantitatif tendensi sentral. Menurut Kadir (2015:53) ukuran kecenderungan memusat atau tendensi sentral adalah ukuran distribusi data yang mempunyai gejala atau kecenderungan memusat pada suatu nilai tertentu. Jenis tendensi sentral yang digunakan dalam penelitian ini adalah mean (rata-rata) yang digunakan dalam menganalisis hasil validasi produk dari ahli materi dan ahli media. Teknik analisis ini digunakan untuk memudahkan peneliti dalam merangkum data dalam bentuk prosentase dan menarik simpulan bukan untuk memberikan generalisasi. Rumus rata-rata tunggal dapat dilihat di bawah ini.

$$
\begin{gathered}
\bar{x}=\frac{x_{1}+x_{2}+x_{3}+\cdots+x_{N}}{N}=\frac{\sum_{j=1}^{N} x j}{N}=\frac{\sum x}{N} \\
\bar{x}=\text { rata-rata } \\
\sum x=\text { jumlah data } \\
N=\text { banyak data }
\end{gathered}
$$

Hasil rata-rata tersebut kemudian dikonversikan berdasarkan skala dari BSNP 2014. Untuk menganalisis data hasil umpan balik praktisi. 
Tabel 1. Konversi 1—4 Menurut BSNP 2014

\begin{tabular}{cc}
\hline Kriteria & Rentang Nilai \\
\hline Kurang Sekali & 1 \\
Kurang & 2 \\
Baik & 3 \\
Baik Sekali & 4 \\
\hline
\end{tabular}

Untuk menganalisis data kuesioner validasi ahli materi, ahli media, dan setelah uji coba produk dari peserta didik, jumlah jawaban setiap butir pernyataan yang diperoleh kemudian dipresentase dengan rumus sebagai berikut.

$$
\frac{\text { Jumlah responden memilih satu kriteria tiap aspek }}{\text { Jumlah reponden X jumlah butir pernyataan tiap aspek }}=100 \%
$$

\section{HASIL DAN PEMBAHASAN}

Penelitian ini menghasilkan sebuah produk berupa buku ajar Bahasa dan Sastra Indonesia terintegrasi pendidikan karakter berdasarkan pendekatan komunikatif SMP Pangudi Luhur 1 Yogyakarta kelas VIII. Penelitian ini mengembangkan produknya dengan menggunakan model pengembangan Borg and Gall yang hanya melalui tahap keenam, yaitu main field testing di kelas VIII D SMP Pangudi Luhur 1 Yogyakarta. Berikut dipaparkan keenam langkah penyusunan buku ajar Bahasa dan Sastra Indonesia terintegrasi pendidikan karakter berdasarkan pendekatan komunikatif SMP Pangudi Luhur 1 Yogyakarta kelas VIII.

Analisis kebutuhan guru dan kepala sekolah dihimpun dengan menggunakan instrumen wawancara, sedangkan analisis kebutuhan peserta didik menggunakan instrumen kuesioner. Sebelum instrumen digunakan, instrumen ini divalidasi oleh ahli agar instrumen ini valid digunakan. Validator tahap ini ada dua orang ahli. Wawancara tertulis itu berisi empat pertanyaan yang harus dijawab oleh kepala sekolah. Berdasarkan wawancara tertulis tersebut didapat jawaban yang sejalan dengan pemikiran peneliti. Untuk pertanyaan nomor satu, dengan pertanyaan "Nilai yayasan apakah yang ingin diusung dalam pendidikan di sekolah ini?
Mengapa?", kepala sekolah menyatakan bahwa nilai yang ingin diusung dalam pendidikan di sekolah ini adalah luhur budi, cerdas, dan humanis. Ketiga nilai yang ingin diusung ini berlatar belakang dengan adanya era globalisasi yang serba terbuka dan berubah, sangat dibutuhkan pribadi yang berbudi luhur, cerdas, sekaligus tetap pribadi yang berkepribadian Indonesia, toleran, dan mencintai sesama.

Selanjutnya, pertanyaan berupa "Dari nilai yang diusung oleh yayasan itu, manakah yang masih belum terinternalisasikan dalam diri peserta didik di sekolah ini? Mengapa?", kepala sekolah memberi jawab berupa nilai yang masih belum terinternalisasikan dalam diri peserta didik di sekolah ini adalah humanis. Hal ini menjadi sesuatu yang krusial karena heterogenitas peserta didik. Heterogenitas ini ditilik dari semakin minimnya kesempatan makan malam dan doa bersama dalam keluarga. Selain itu, intensitas perjumpaan anak dengan orang tua dalam keluarga berkurang. Hal inilah yang dapat menjadi salah satu faktor, sehingga tidak mudah juga untuk sekolah mentransfer nilai tersebut.

Pertanyaan ketiga yang ditanyakan kepada kepala sekolah adalah "Usaha apakah yang dilakukan oleh sekolah untuk dapat menginternalisasikan nilai yang diusung oleh yayasan di sekolah ini? Mengapa?". Kepala sekolah dengan tegas menjawab cara yang dilakukan saat ini adalah dengan komparatif. Hal ini dilakukan dengan adanya keeratan hati, budi, pikiran, dan diwujudkan dalam kegiatan yang rohani, outing, bakti sosial, dan lain-lain.

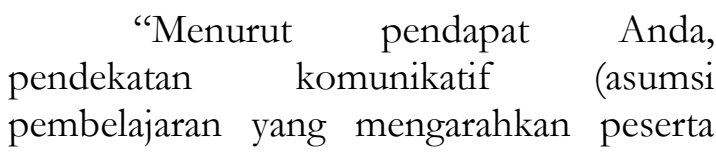


didik untuk dapat menggunakan fungsi komunikasi dalam bahasa) dan pendidikan karakter perlu dijunjung di sekolah ini atau tidak? Mengapa?" adalah pertanyaan terakhir yang diajukan kepada kepala sekolah. Kepala sekolah menjawab dengan singkat, "Perlu sekali". Menurut beliau, sesuatu yang baik tanpa dikomunikasikan dengan baik tidak akan dipahami dan dilaksanakan dengan baik.

Berdasarkan wawancara tertulis yang dilakukan terhadap Kepala SMP Pangudi Luhur 1 Yogyakarta ini dapat disimpulkan beberapa hal penting. Beberapa hal tersebut adalah nilai-nilai yang ingin diusung oleh sekolah adalah luhur budi, cerdas, dan humanis. Namun, dari ketiganya nilai humanislah yang belum dapat terinternalisasi dalam diri peserta didik di sekolah tersebut. Humanitas belum dapat terinternalisasi dalam diri peserta didik disebabkan dalam keluarga setiap peserta didik yang heterogen. Untuk mengatasi persoalan tersebut, sekolah sudah melakukan beberapa kegiatan yang berkaitan denga rohani, outing, dan bakti sosial. Harapan dari kegiatan ini tentunya untuk mengasah humanitas dalam diri setiap peserta didik. Hal penting selanjutnya adalah pendekatan komunikatif dan pendidikan karakter perlu dijunjung di sekolah ini. Harapannya adalah agar segala sesuatu yang baik dapat dikomunikasikan dengan baik dan dapat dipahami serta dilaksanakan dengan baik. Selanjutnya, akan dipaparkan hasil wawancara dengan guru Bahasa Indonesia SMP Pangudi Luhur 1 Yogyakarta.

Adapun hasil wawancara terhadap guru mata pelajaran Bahasa Indonesia didapatkan simpulan bahwa kesulitan yang dialami oleh tiga guru dalam mengembangkan materi pembelajaran Bahasa Indonesia adalah menyusun materi dalam bentuk bahan ajar/buku teks. Hal ini disebabkan sang guru menyiapkan materi hanya dalam bentuk lembaran, belum menjadi buku teks. Lembaran itu lalu difotokopi sejumlah peserta didik dan dibagikan begitu saja. Cara penyajian yang materi yang paling sering digunakan oleh guru dalam pembelajaran bahasa Indonesia adalah diskusi dan penugasan. Namun, ada juga tiga guru yang menggunakan tanya jawab dan ada dua orang guru dengan cara ceramah. Alasan dari kelima guru itu pun bermacam-macam. Ada yang merasa empat cara, yaitu: ceramah, tanya jawab, diskusi, dan penugasan paling cocok dan mudah dilakukan oleh pendidik dan peserta didik. Ada yang mengatakan bahwa semuanya sangat sering dilaksanakan dan dikombinasikan dalam setiap pertemuan. Ada yang berpendapat dengan adanya penugasan, pembelajaran berjalan dengan tenang dan tetap kondusif. Selain itu, cara tanya jawab, diskusi, dan penugasan akan lebih mempermudah peserta didik.

Evaluasi pembelajaran Bahasa Indonesia terhadap peserta didik sudah dilakukan oleh guru secara optimal. Hal ini terlihat dari sejumlah evaluasi yang telah dilaksanakan. Jenis evaluasi yang telah dilakukan adalah evaluasi formatif dalam bentuk teks subjek, evaluasi melalui hasil pekerjaan peserta didik, evaluasi sumatif (akhir semester) dalam bentuk tes subjektif, melakukan tugas akhir secara individu, memberikan tugas akhir secara kelompok, dan memberikan evaluasi tengah semester. Tes ini dilakukan untuk mengetahui pemahaman peserta didik terhadap materi. Namun, dari beberapa jenis evaluasi tersebut, belum terlihat adanya penilaian sikap yang dilakukan oleh guru. Hal ini terjadi karena berdasarkan Kurikulum 2013 revisi 2014 tidak mengaitkan lagi penilaian sikap terhadap peserta didik dalam pembelajaran Bahasa Indonesia.

Menurut pendapat dari kelima guru Bahasa Indonesia di SMP Pangudi Luhur 1 Yogyakarta mengenai nilai yayasan yang belum tercapai dalam pembelajaran Bahasa Indonesia adalah peduli lingkungan, sepenuh hati, dan humanis. Hal ini diutarakan oleh para guru karena ada beberapa alasan. Alasan pertama yang mengenai kekurangpedulian terhadap lingkungan adalah karena banyak kertaskertas yang dipotong dan dalam keseharian banyak yang membuang sampah tidak pada tempatnya. Berkaitan dengan nilai sepenuh 
hati, guru mengatakan bahwa peserta didik dalam belajar masih banyak yang hanya setengah atau tidak sungguh-sungguh dalam belajar. Adapun nilai humanis yang belum terinternalisasikan dalam diri peserta didik dikarenakan masih banyak peserta didik yang kurang memiliki rasa hormat terhadap para gurunya, terutama ketika berada di luar kelas (dalam lingkungan sekolah).

Tanggapan atas pertanyaan berupa "Dalam penerapan pembelajaran, sudahkah pendekatan komunikatif dilaksanakan sesuai dengan prosedur? Mengapa?" tanggapan yang variatif disampaikan oleh para guru Bahasa Indonesia di SMP Pangudi Luhur 1 Yogyakarta. Ada seorang guru yang menyatakan bahwa pendekatan komunikatif sudah dilaksanakan. Hal ini dinyatakan dengan adanya fakta di dalam kelas mengenai peserta didik yang sudah sering berlatih secara intesif untuk berkomunikasi, misalnya: berpidato, bermain drama, dan lain-lain. Adapun guru yang menyatakan bahwa sudah menerapkan, tetapi untuk tingkat keberhasilan ke peserta didik masih belum merata. Hal ini disebabkan ada peserta didik yang capat dalam menyerap materi pelajaran, sehingga penerapan komunikasi dapat terjadi. Namun, sebagian besar alokasi waktu tidak cukup dalam penyerapan materi. Akibatnya, guru sulit menerapkan pendekatan komunikatif. Selain itu, ada faktor lain yang membuat pendekatan komunikatif sulit diterapkan. Faktor itu adalah beberapa peserta didik dirasa kurang menyukai pembelajaran Bahasa Indonesia. Hal ini membuat peserta didik malu dan takut salah untuk dapat menerapkan pendekatan komunikatif.

Urgensi pembelajaran bahasa Indonesia terintegrasi dengan pendekatan komunikatif berbasis pendidikan karakter di sekolah ini sangat penting. Hal ini disebabkan dalam kelas bahasa Indonesia, belum banyak peserta didik yang mau untuk menunjukkan kemampuannya berbicara lisan di depan umum. Guru menganalisis bahwa alasannya bukan karena malu, tetapi ada hal yang tersembunyi dan belum dapat dipecahkan oleh guru. Guru lebih melihat pada apakah peserta didik memiliki trauma buruk terhadap pelajaran bahasa Indonesia atau bahasa Indonesia bagi mereka bukan mata pelajaran yang penting.

Adapun analisis kebutuhan dengan kuesioner kepada peserta didik dapat disimpulkan sebagai berikut. Materi pembelajaran Bahasa Indonesia sudah menunjukkan karakter diri bangsa. Pembelajaran Bahasa Indonesia banyak mempelajari tata bahasa Indonesia. Selain itu, banyak mempelajari ejaan bahasa Indonesia (tata tulis). Pemberian contohcontoh dalam pembelajaran bahasa Indonesia memudahkan peserta didik memahami materi pelajaran. Materi pembelajaran mampu mengembangkan kemampuan berbahasa Indonesia peserta didik. Materi pelajaran membantu peserta didik untuk menghargai orang lain. Bahan ajar berbasis teks sering digunakan dalam pembelajaran bahas Indonesia. Bahan ajar tugas (main peran, simulasi, dan aktivitas) digunakan dalam pembelajaran bahasa Indonesia. Namun, bahan ajar majalah tidak sering digunakan untuk pembelajaran bahasa Indonesia. Surat kabar sering digunakan untuk pembelajaran bahasa Indonesia. Materi menggunakan gambar cukup sering digunakan untuk pembelajaran bahasa Indonesia. Iklan pernah digunakan untuk materi pembelajaran bahasa Indonesia. Peserta didik mudah memahami ejaan bahasa Indonesia. Peserta didik banyak yang suka belajar bahasa dengan langsung berkomunikasi. Selain itu, peserta didik sudah dapat berkomunikasi dengan baik saat pelajaran bahasa Indonesia.

Tugas dalam pembelajaran bahasa Indonesia sering dengan tugas tertulis. Namun, mempraktikkan secara langsung membuat peserta didik lebih memahami pelajaran bahasa Indonesia. Peserta didik dapat memahami materi teks diskusi dalam bahasa Indonesia dengan adanya terjun langsung dalam kegiatan diskusi di masyarakat. Peserta didik lebih senang tugas membuat teks ulasan dengan 
membaca bukunya langsung. Tugas bahasa Indonesia tidak selalu berupa keterampilan menulis dan berbicara. Penugasan secara berkelompok dapat membantu peserta didik lebih menghargai orang lain. Penugasan dalam pembelajaran bahasa Indonesia membuat peserta didik mandiri. Memberi tanggapan lisan digunakan dalam pemberian tugas di kelas bahasa Indonesia. Tugas yang diberikan berupa merangkum atau meringkas suatu teks sesuai dengan bahasa di pelajaran bahasa Indonesia lebih dapat memahamkan peserta didik. Berdiskusi dilakukan selama pembelajaran bahasa Indonesia dan menceritakan kembali teks yang digunakan membantu proses pembelajaran. Namun, mewawancarai seseorang tidak digunakan dalam pembelajaran bahasa Indonesia, padahal peserta didik senang penugasan secara berkelompok dan mandiri yang nyata.

Soal-soal tes sesuai dengan materi yang diajarkan sebelumnya. Penilaian yang dilakukan adalah dengan tes tertulis. Tampil di depan kelas digunakan untuk penilaian bahasa Indonesia. Begitu pula, tanya jawab saat pembelajaran dilakukan oleh guru dalam pembelajaran bahasa Indonesia. Pengamatan atau observasi dilakukan untuk menilai pembelajaran bahasa Indonesia. Penilaian diri sendiri dan teman sejawat (seusia) pun dilakukan dalam penilaian bahasa Indonesia. Namun, peserta didik senang bila dinilai dengan tes tertulis. Hal itu berarti peserta didik tidak senang bila dinilai dengan tes lisan. Namun, peserta didik senang bila dinilai dengan tes perbuatan. Begitu pula dengan penilaian observasi (pengamatan), skala sikap (penilaian sikap dengan rentang poin), dan dinilai dengan daftar cek peserta didik juga senang bila dinilai dengan itu. Namun, peserta didik tidak senang bila dinilai dengan wawancara. Adapun soal-soal tes sesuai dengan materi yang diajarkan sebelumnya.

Berdasarkan analisis kebutuhan terhadap pengembangan buku ajar Bahasa dan Sastra Indonesia Terintegrasi Pendidikan Karakter Berdasarkan
Pendekatan Komunikatif di SMP Pangudi Luhur 1 Yogyakarta dapat disimpulkan bahwa pengintegrasian pendidikan karakter diperlukan pada peserta didik, terutama kelas VIII pada nilai cinta lingkungan dan humanitas. Selain itu, pembelajaran berdasarkan pendekatan komunikatif juga sangat diperlukan agar peserta didik dapat menggunakan bahasa sesuai dengan fungsinya dan melatih kepercayaan diri peserta didik.

Peneliti kembali mengonfirmasi hasil kesimpulan analisis kebutuhan pada Kepala Sekolah, Wakil Kepala Bidang Kurikulum, dan guru mata pelajaran Bahasa Indonesia. Berdasarkan konfirmasi yang dilakukan peneliti, Kepala Sekolah, Wakil Kepala Bidang Kurikulum, dan guru mata pelajaran Bahasa Indonesia menyetujui simpulan yang diambil oleh peneliti dan sesuai dengan visi misi sekolah.

Proses tersebut berlanjut dengan pengembangan produk dan validasi intrumen validasi produk. Pengembangan produk disesuaikan dengan hasil analisis kebutuhan yang telah dilakukan dan dengan mengacu bebarapa teori tentang pengembangan buku ajar dan teori integrasi pendidikan karakter berdasarkan pendekatan komunikatif. Validasi instrumen validasi produk dilakukan untuk mengabsahkan setiap instrumen agar menguku apa yang seharusnya diukur. Berdasarkan hasil validasi instrumen validasi produk, peneliti harus mengubah redaksional yang digunakan, mengeliminasi butir yang redudansi, serta menegaskan lagi apa yang dimaksud dengan kelayakan produk.

Pengembangan buku ajar yang dikembangkan berupa empat aspek, yaitu aspek kompetensi, aspek materi, aspek tugas, dan aspek penilaian. Keempat aspek ini dikembangkan mengacu pada Kurikulum 2013 revisi 2017 dan mengintegrasikan pendidikan karakter di dalam setiap aspek dan berdasarkan pendekatan komunikatif. Nilai dalam pendidikan karakter yang ditonjolkan dalam buku ajar ini adalah humanitas (memanusiakan manusia) dan cinta 
lingkungan. Hal ini terimplementasi dari rumusan tujuan dalam RPP yang digunakan dalam pembelajaran dengan menggunakan buku ajar ini, materi teks yang dipilih, tugas-tugas yang diberikan diminta untuk selalu merefleksikan nilai yang diperoleh, penilaian dengan tiga aspek (sikap, pengetahuan, dan keterampilan), aksi melakukan sesuatu sesuai nilai yang dipelajari dan diperoleh, dan adanya permainan bola musik.

Pemilihan materi dalam buku ajar adalah berupa teks autentik (dapat dipercaya, asli) yang mengandung nilai-nilai tertentu, terutama nilai cinta lingkungan dan humanitas. Tugas-tugas yang dikembangkan dalam buku ajar ini adalah tugas yang mencakup ketiga aspek (aspek sikap, aspek pengetahuan, dan aspek keterampilan). ketiga aspek ini direalisasikan atau diwujudnyatakan dalam bentuk kalimat tanya dan atau kalimat perintah. Adapun pengembangan penilaian dalam buku ajar ini adalah pencantuman tabel berisi ketiga aspek yang dinilai (aspek sikap, aspek pengetahuan, dan aspek keterampilan) yang diletakkan secara susun bawah dalam tabel yang berbeda untuk setiap aspek. Pada setiap aspek masih diuraikan dalam beberapa subaspek yang dinilai disertai dengan skor yang telah ditentukan berdasarkan esensi atau prioritas penilaian.

Buku ajar ini juga dikembangkan kolom refleksi pada setiap akhir penilaian. Tidak hanya refleksi yang tercantum setelah kolom penilaian, tetapi juga terdapat kolom aksi. Dalam refleksi disajikan tuntunan isian singkat berkenaan dengan aspek sikap, aspek kognitif, dan aspek keterampilan. Setelah itu disajikan kolom aksi, peserta didik diminta untuk mendokumentasikan aksinya. Lalu, peserta didik mengunggah pada akun media sosialnya dengan menandai sang guru. Tentunya, caption yang ditulis tetap menandakan bahwa peserta didik sangat komunikatif. Kolom aksi ini dituntun dengan kalimat perintah. Selain itu, di setiap akhir bab disajikan panduan permainan bola musik. Dengan adanya permainan bola musik, peserta didik diminta untuk menghargai sesama, mengikuti aturan main, dan tertib.

Produk yang sudah jadi siap untuk divalidasi oleh ahli materi dan ahli media. Berdasarkan hasil validasi kedua validator ini didapatkan hasil validator materi terhadap produk berada pada aspek kelayakan isi, yaitu 6,25\% kategori "kurang baik", 12, 5\% kategori "baik", dan 81,25\% kategori "sangat baik". Pada aspek komponen penyajian, yaitu $5 \%$ kategori "kurang baik", 30\% kategori "baik", 65\% kategori "sangat baik". Aspek kelayakan bahasa 62,5\% kategori "baik" dan 37,5\% kategori "sangat baik". Aspek integrasi pendidikan karakter dan dasar pendekatan komunikatif keduanya 50\% kategori "baik" dan 50\% kategori "sangat baik". Adapun hasil validasi media terhadap produk berapa pada aspek ukuran buku 50\% kategori "baik" dan 50\% kategori "sangat baik". Aspek desain kover buku 19,4\% kategori "kurang baik", 36\% kategori "baik", dan 44\% kategori "sangat baik". Aspek desain isi buku 25\% kategori "kurang baik", $41,17 \%$ kategori "baik", dan 33,82\% kategori "sangat baik".

Setelah itu, produk diujicobakan di kelas VIII D SMP Pangudi Luhur 1 Yogyakarta pada Kamis, 25 Juli 2019. Berdasarkan hasil penilaian peserta didik terhadap produk buku ajar pada aspek kemenarikan buku ajar 1,87\% pada kategori "tidak baik", 4,68\% kategori "kurang baik", 67,18\% kategori "baik", dan 26,25\% kategori "sangat baik". Aspek isi buku ajar 0,44\% kategori "tidak baik", 3,5\% kategori "kurang baik", 74,10\% kategori "baik", dan $22,76 \%$ kategori "sangat baik". Aspek bahasa buku ajar 1,56\% kategori "tidak baik", 1,56\% kategori "kurang baik", $73,43 \%$ kategori "baik", dan 23,43\% kategori "sangat baik". Dari hasil tersebut, secara keseluruhan menggambarkan bahwa produk penelitian ini tidak perlu direvisi karena penilaian produk secara umum dinilai baik untuk digunakan. Adapun penilaian praktisi (guru Mata Pelajaran Bahasa Indonesia) mencapai nilai rata-rata $=$ $67 / 19=3,526$. Nilai rata-rata ini masuk dalam kategori "Baik". Berdasarkan kedua 
jenis kuesioner umpan balik tersebut, respon peserta didik dan guru cenderung konsisten, yaitu penilaian keduanya berada dalam kategori "Baik".

\section{SIMPULAN}

Analisis kebutuhan dilakukan pada awal penelitian dengan maksud mengetahui kebutuhan peserta didik, guru, kepala sekolah, dan sekolah terhadap buku ajar yang sudah ada dan digunakan selama pembelajaran ini. Tidak hanya kebutuhan terhadap buku ajar, tetapi juga karakteristik peserta didik dan visi misi yang diusung oleh sekolah ini. Berdasarkan hasil analisi kebutuhan yang telah dilakukan muara dari pendidikan karakter yang ingin diusung lebih ekstra lagi adalah nilai humanitas dan cinta lingkungan. Selain itu, terkait dengan pendekatan komunikatif, ternyata masih banyak peserta didik yang belum optimal dalam berkomunikasi, walaupun sudah dikatakan baik. Namun, baik yang dimaksud hanya dalam beberapa aspek saja, terutama saat diskusi lepas. Ketika dihadapkan pada presentasi belum banyak peserta didik yang dengan penuh percaya diri mengemukakan pendapat atas hasil temuannya. Maka dari itu, pengembangan buku ajar Bahasa dan Sastra Indonesia terintegrasi pendidikan karakter berdasarkan pendekatan komunikatif sangat diperlukan di sekolah ini.

Pengembangan buku ajar yang dikembangkan adalah kompetensi, materi, tugas, dan penilaian. Keempat aspek ini dikembangkan mengacu pada Kurikulum 2013 revisi 2017 dan mengintegrasikan pendidikan karakter di dalam setiap aspek dan pendekatan komunikatif. Nilai dalam pendidikan karakter yang ditonjolkan dalam buku ajar ini adalah humanitas (memanusiakan manusia) dan cinta lingkungan. Hal ini terimplementasi dari rumusan tujuan dalam RPP yang digunakan dalam pembelajaran dengan menggunakan buku ajar ini, materi teks yang dipilih, tugas-tugas yang diberikan diminta untuk selalu merefleksikan nilai yang diperoleh, penilaian dengan tiga aspek (sikap, pengetahuan, dan keterampilan), aksi melakukan sesuatu sesuai nilai yang dipelajari dan diperoleh, dan adanya permainan bola musik. Dalam aksi, peserta didik diminta untuk mendokumentasikan aksinya. Lalu, peserta didik mengunggah pada akun media sosialnya dengan menandai sang guru. Tentunya, caption yang ditulis tetap menandakan bahwa peserta didik sangat komunikatif. Dengan adanya permainan bola musik, peserta didik diminta untuk menghargai sesama, mengikuti aturan main, dan tertib.

Penelitian pengembangan ini masih banyak kekurangan yang dapat dikembangkan lagi oleh peneliti lain yang memiliki kemampuan dan keinginan untuk melanjutkan penelitian ini. Kekurangan penelitian ini adalah dalam tahap pengembangan Borg and Gall yang belum sepenuhnya dilakukan dalam sepuluh tahap. Selain itu, masih ada peluang peneliti lain untuk melakukan revisi terhadap buku ajar yang telah dikembangkan, membuat buku elektronik yang menarik, dan membuat gambar sendiri untuk semua gambar yang digunakan dalam buku ajar.

\section{DAFTAR RUJUKAN}

Hosnan. (2014). Pendekatan Saintifik dan Kontekstual dalam Pembelajaran Abad 21: Kunci Sukses Implementasi Kurikulum 2013. Bogor: Ghalia.

Irawati, R. P., \& Elmubarok, Z. (2014). Pengembangan Buku Ajar Bahasa Indonesia Tematik Berkarakter Bagi Siswa SD melalui Sastra Anak. Jurnal Pendidikan Karakter, (2).

Kemendikbud. (2017). Model Silabus Mata Pelajaran SMP/MTs Mata Pelajaran Bahasa Indonesia. Jakarta: Kemendikbud.

Kurniawan, S. (2013). Pendidikan Karakter: Konsepsi \& Implementasinya secara Terpadu di Lingkungan Keluarga, Sekolah, Perguruan Tinggi, dan Masyarakat. Cetakan I. Yogyakarta: Ar-Ruzz Media.

Lickona, T. (2013). Character Matters: Persoalan Karakter Bagaimana Membantu Anak Mengembangkan 
Penilaian yang Baik, Integritas, dan Kebajikan Penting Lainnya. Cetakan II. Jakarta: Bumi Aksara.

Listyarti, R. (2012). Pendidikan Karakter dalam Metode Aktif, Inovatif, dan Kreatif. Jakarta: Esensi.

Nurdyansyah, N., \& Lestari, R. P. (2018). Pembiasaan Karakter Islam Dalam Pengembangan Buku Ajar Bahasa Jawa Piwulang 5 Pengalamanku Kelas I MI Nurur Rohmah Jasem Sidoarjo. MIDA: Jurnal Pendidikan Dasar Islam, 1(2), 35-49.

Rabawati, K., Sutama, M., \& Gosong, M. (2013). Penerapan Pendekatan Komunikatif dalam Pembelajaran Bahasa Indonesia Siswa Kelas XI Smk Negeri 1 Denpasar. Jurnal Pendidikan dan Pembelajaran Babasa Indonesia, 2.

Riyanto, A. (2013). Pengembangan Buku Pengayaan Keterampilan Membaca Bahasa Indonesia yang Bermuatan Nilai Kewirausahaan. Seloka: Jurnal Pendidikan Bahasa dan Sastra Indonesia, 2(1).

Setiawati, L. (2015). Pembentukan Karakter siswa Melalui Pembelajaran Bahasa dan Sastra Indonesia. Jurnal Pendidikan, 16(1), 65-73.
Situmorang, M. (2014). Pengembangan buku ajar kimia Sma melalui inovasi pembelajaran dan integrasi pendidikan karakter untuk meningkatkan hasil belajar siswa. Prosiding SEMIRATA 2013, 1(1).

Sugiyono. (2015). Metode Penelitian dan Pengembangan Research and Development unutk Bidang Pendidikan, Manajemen, Sosial, Teknik. Bandung: Alfabeta.

Suwarni, E. (2015). Pengembangan Buku Ajar Berbasis Lokal Materi Keanekaragaman Laba-Laba di Kota Metro Sebagai Sumber Belajar Alternatif Biologi Untuk Siswa SMA Kelas X. Bioedukasi, 6(2).

Tarigan, H.G. (1988). Metodologi Pengajaran Bahasa. Bandung: Depdikbud.

Tolla, A. (1996). Kajian Pendekatan Komunikatif dalam Pengajaran Bahasa Indonesia di Sekolah Menengah Umum. Artikel Disertasi Doktor dalam bidang Pendidikan Bahasa pada program Pascasarjana IKIP Malang.

Wahyuni, S., \& Ibrahim, A.S. (2013). Perencanaan Pembelajaran Babasa Berkarakter. Cetakan II. Bandung: Refika Aditama. 